\title{
Influence Of Host Genetic Origin And Geographic Location On Qpx Disease In Northern Quahogs (=Hard Clams), Mercenaria Mercenaria
}

LMR Calvo

SE Ford

JN Kraeuter

DF Leavitt

R Smolowitz

See next page for additional authors

Follow this and additional works at: https://scholarworks.wm.edu/vimsarticles

Part of the Marine Biology Commons

\section{Recommended Citation}

Calvo, LMR; Ford, SE; Kraeuter, JN; Leavitt, DF; Smolowitz, R; and Burreson, EM, Influence Of Host Genetic Origin And Geographic Location On Qpx Disease In Northern Quahogs (=Hard Clams), Mercenaria Mercenaria (2007). Journal Of Shellfish Research, 26(1), 109-119.

https://scholarworks.wm.edu/vimsarticles/445 


\section{Authors}

LMR Calvo, SE Ford, JN Kraeuter, DF Leavitt, R Smolowitz, and EM Burreson 


\title{
INFLUENCE OF HOST GENETIC ORIGIN AND GEOGRAPHIC LOCATION ON QPX DISEASE IN NORTHERN QUAHOGS (= HARD CLAMS), MERCENARIA MERCENARIA
}

\author{
LISA M. RAGONE CALVO, ${ }^{1 *}$ SUSAN E. FORD,${ }^{2}$ JOHN N. KRAEUTER,${ }^{2}$ DALE F. LEAVITT, ${ }^{3}$ \\ ROXANNA SMOLOWITZ ${ }^{4}$ AND EUGENE M. BURRESON ${ }^{1}$ \\ ${ }^{1}$ Virginia Institute of Marine Science, College of William and Mary, P.O. Box 1346, Rt. 1208, Gloucester \\ Point, VA 23062; ${ }^{2}$ Haskin Shellfish Research Laboratory, Rutgers University, Port Norris, NJ 08349; \\ ${ }^{3}$ Roger Williams University, Bristol, RI 02809; ${ }^{4}$ Marine Biological Laboratory, Woods Hole, MA 02543
}

\begin{abstract}
QPX (Quahog Parasite Unknown) a protistan pathogen of northern quahogs (=hard clams), Mercenaria mercenaria, has caused disease outbreaks in maritime Canada, and in Massachusetts, New York, New Jersey, and Virginia, USA. Although epizootics have occurred in wild hard clam populations, the parasite has most seriously affected cultured hard clams, suggesting that aquaculture practices may promote or predispose clams to the disease. In this investigation the influence of clam genetic origin and the geographic location at where they are grown on QPX disease susceptibility was examined in a common garden experiment. Aquaculture stocks were acquired from hatcheries in Massachusetts, New Jersey, Virginia, South Carolina, and Florida and spawned at a single hatchery in Virginia. All stocks were originally, although not exclusively, derived from wild hard clam populations from each state. The seed clams were deployed at two sites, New Jersey and Virginia, and evaluated during the subsequent 2.5 y for growth, survival, and QPX disease. At both sites, South Carolina- and Florida-derived clam stocks exhibited significantly higher QPX prevalence and lower survival than New Jersey and Massachusetts clam stocks. Levels in the Virginia stock were intermediate. In Virginia, mortality at the termination of the experiment was $78 \%, 52 \%, 36 \%, 33 \%$, and $20 \%$ in the Florida, South Carolina, Virginia, Massachusetts, and New Jersey hard clam stocks, respectively. Mortality was significantly correlated with QPX prevalence. Maximum QPX prevalence in the South Carolina and Florida stocks ranged from $19 \%$ to $21 \%$ and $27 \%$ to $29 \%$, respectively, whereas in the Virginia, New Jersey, and Massachusetts stocks prevalence was $10 \%$ or less. Similar trends were observed in New Jersey where mortality at the termination of the experiment was estimated to be $53 \%, 40 \%, 20 \%, 6 \%$, and $4 \%$ in the Florida, South Carolina, Virginia, Massachusetts, and New Jersey clam stocks, respectively. QPX prevalence peaked at $18 \%$ in the Florida stock, 38\% in the South Carolina, 18\% in the Virginia, and 5\% in the New Jersey and Massachusetts stocks. These results suggest that host genotype is an important determinant in susceptibility to QPX disease. As such, hard clam culturist should consider the genetic origin of clam seed stocks an important component of their QPX disease avoidance/management strategies.
\end{abstract}

KEY WORDS: QPX, quahog hard clam, Mercenaria, parasite, disease, genetics, environment, aquaculture

\section{INTRODUCTION}

Wild and cultured northern quahogs (= hard clams), Mercenaria mercenaria represent an important natural resource in coastal and estuarine lagoons along the east coast of the United States. Wild stocks have long supported commercial and recreational fisheries in these areas; however, in some regions harvests have been declining over the last two decades. In contrast, aquaculture production of hard clams has increased in the last $25+$ years. Clams are being cultured along the eastern seaboard of the United States from Maine to Florida.

Unlike other bivalve aquaculture species, hard clam seed cannot be found naturally in quantities suitable for commercial applications, and hard clam aquaculture is solely dependent on hatchery-produced seed. Commercial hatcheries have developed from Maine to Florida. These hatcheries supply hundreds of farms with seed and a significant amount of seed is transferred between states. Because of industry's dependence on hatchery production of juvenile clams, and because clam seed is often in short supply, growers often plant whatever seed is available or costs the least when they are ready to plant. The genetic composition of clam seed can vary significantly from region to region (Menzel 1989) and genetic data and anecdotal

*Corresponding author. E-mail: calvo@hsrl.rutgers.edu Current address: Haskin Shellfish Research Laboratory, Rutgers University, Port Norris, NJ 08349 evidence suggests that growth and survival traits are heritable (Hilbish 2001). Commercial hatcheries and research institutions have used selective breeding strategies to enhance hard clam growth and survival performance; however, rigorous genetic studies have been limited and there is great potential for marked enhancement of economically important performance characteristics through further domestication.

Historically disease has not been a problem for the industry, but in the early1990s QPX emerged as a locally serious disease problem and has caused significant losses of cultured hard clams in Massachusetts (Smolowitz et al. 1998), New Jersey (Ford et al. 2002) and Virginia (Ragone Calvo et al. 1998); and of wild clams in Massachusetts and New York (Smolowitz unpublished, Dove et al. 2004). The epizootiology of QPX is poorly understood. Based on morphological and molecular analyses, QPX is a protist that has been tentatively classified as a member of the Thraustochytriidae family within the phylum Labyrinthulomycota (Whyte et al. 1994, Maas et al. 1999, Ragan et al. 2000, Stokes et al. 2002). Thraustochytrids are widely distributed in marine and estuarine environments and typically are associated with detrital sediments, benthic algae, and marine plants. Several organisms within the phylum can cause disease (Polglase 1980, McLean \& Porter 1982, Bower 1987).

It seems that QPX, like other thraustochytrids, is widely distributed in areas from Canada to at least as far south as Virginia. QPX may be an opportunistic parasite, which may cause marked morbidity and mortality in clams that are 
disadvantaged. The parasite has not been found in hatchery seed suggesting it is acquired after planting (Ford et al. 1997).

Little is known about interactions between QPX, the hard clam, and the environment. Severe outbreaks of the disease in dense wild hard clam populations in Canada, New York, and New Jersey point to host density as an important factor in QPX epizootics. Ford et al. (2002) found that QPX prevalence increased with increased planting density in a field experiment; however, the trend was not statistically significant. The parasite appears to be more prevalent in cultured clam plots than in wild clam populations suggesting that culture practices may increase the susceptibility of clams to QPX. Increased density might play an important role, but another aquaculture-associated factor that seems to be important is seed source. Under present culture practices aquacultured seed may originate from non-local stocks and sources. Anecdotal evidence from Massachusetts, suggested that nonlocal clams imported from New Jersey suffered greater losses to QPX than local stocks. In New Jersey, clams originating from South Carolina clam lineages exhibited heavy QPX infections and suffered mortalities of $26 \%$ to $92 \%$, whereas clams from local New Jersey stocks, planted in adjacent plots, exhibited few QPX infections and experienced little mortality (Ford et al. 2002). Ford et al. (2002) suggest that QPX causes disease and mortality in non-local clam stocks that may be disadvantaged in some way, perhaps by unfavorable genotype-environment interactions.

Selection of clam seed may be an achievable management strategy for QPX disease avoidance. In developing such a strategy it is important to understand the interactions between host genetics and QPX disease dynamics. This study examined the effects of genetic origin of source populations and the geographic location in which they are grown on host susceptibility and QPX pathogenicity.

\section{METHODS}

\section{Nursery and Hatchery Production of Test Stocks}

Five clam stocks, representing lines from 5 geographic origins, Massachusetts (MA), New Jersey (NJ), Virginia (VA), South Carolina (SC), and Florida (FL), were produced in spring 1999 at the Virginia Institute of Marine Science (VIMS). Brood stocks for the study strains were obtained from commercial and research hatcheries from the respective states. All of the stocks had been selectively bred for fast growth through at least several generations and were presently being used by industry. All stocks were originally, although not exclusively, derived from wild hard clam populations from each state. Clams were reared following standard hatchery techniques and clam seed was then grown in upwellers at VIMS in Wachapreague, VA until planting in October 1999.

\section{Initial Planting and Grow-out of Seed}

In October 1999, clam seed was planted at QPX enzootic areas in Virginia, New Jersey, and Massachusetts. However, we report here only on the results from the Virginia and New Jersey sites as significant weather related losses of clam seed occurred early in the study at the Massachusetts location. The extent of the loss was initially underestimated and subsequent sample numbers were too low for rigorous statistical analyses. The Virginia site was located in an intertidal area of Burton Bay $\left(37^{\circ} 35^{\prime}, 75^{\circ} 37^{\prime}\right)$ (Fig. 1). Salinity at the site ranged from $28-33$ ppt and the sediment was sandy. The New Jersey site was located in Tuckerton $\left(39^{\circ} 32^{\prime}, 74^{\circ} 20^{\prime}\right)$ in a low intertidal area with salinity ranging from $29-33 \mathrm{ppt}$ and muddy sediments (Fig. 1). In each location, four replicate $5 \mathrm{ft} \times 5 \mathrm{ft}(1.52 \mathrm{~m} \times$ $1.52 \mathrm{~m}$ ) plots of each strain were planted at a density of 50 clams

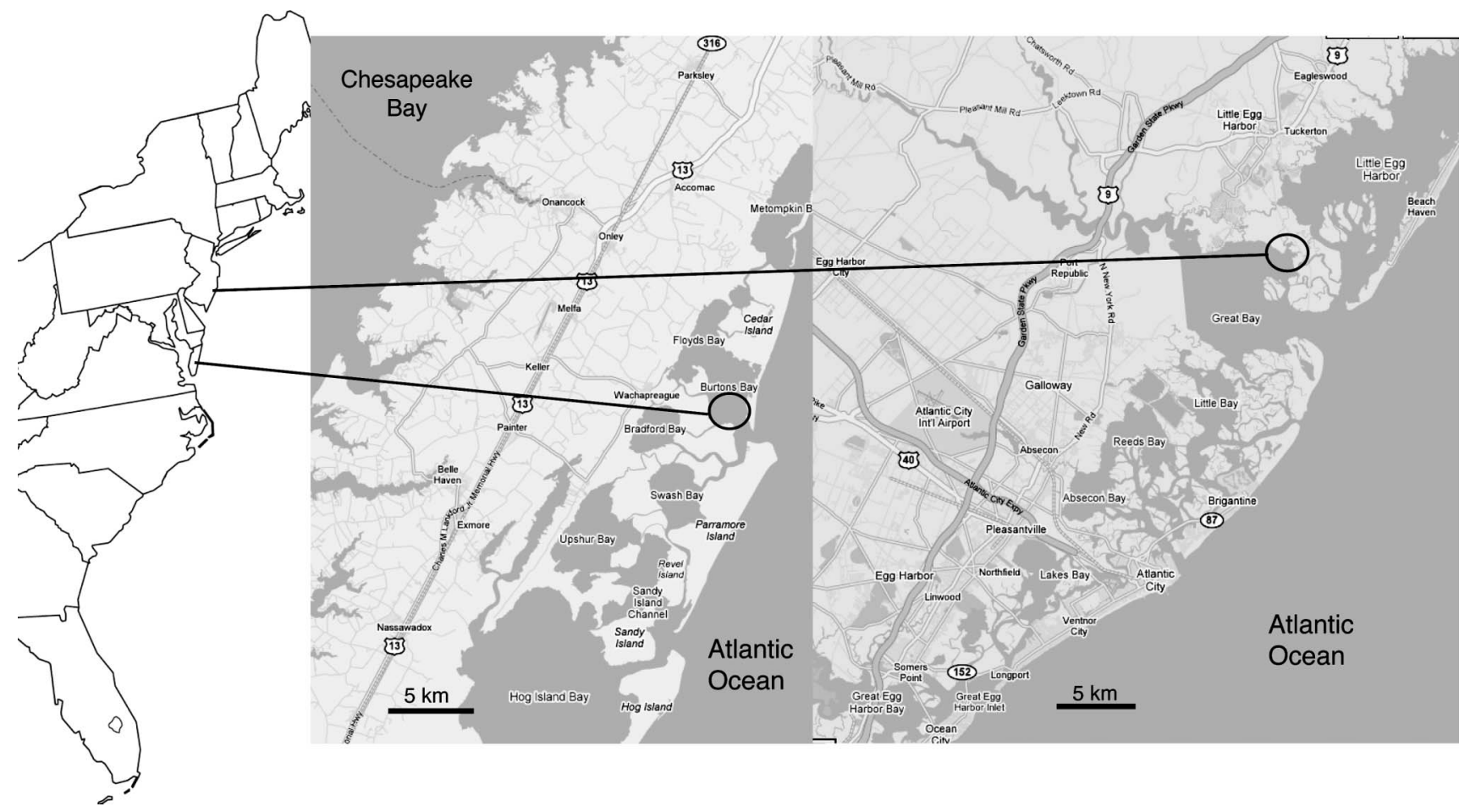

Figure 1. Maps showing the locations of the New Jersey and Virginia field sites. Maps derived using http://maps.google.com. 
$\mathrm{ft}^{-2}$ (538 clams $\left.\mathrm{m}^{-2}\right)$ (1,250 clams per plot, 5,000 per strain, 25,000 per location). These densities are similar to those used by commercial operations, but are considerably higher than most reported natural population densities (Fegley 2001). Replicate plots were distributed according to a randomized block design. Distance between plots was approximately $0.61 \mathrm{~m}$. Clam seed was evenly broadcast within the plots and $0.5^{\prime \prime}(12.7 \mathrm{~mm})$ mesh netting was secured on top of the plots to reduce predation. The plots were examined biweekly to monthly and nets were cleaned as required by collaborating industry members and or project personnel. Prior to field deployment an initial sample of 60 clams from each stock was examined for parasites and disease using standard histological methods.

\section{Replanting of the New Jersey Site}

Severe winter conditions in early 2000 resulted in significant losses of clam seed at the New Jersey site. In New Jersey protective nets were lost as a result of icing and predation by ducks caused nearly a total loss of the stocks. This site was replanted in June 2000 with seed from the original spawns of the MA, NJ, SC and FL stocks, which had overwintered in floats in Wachapreague, VA. Unfortunately no seed was available from the originally spawned VA stock. As a substitute a second Virginia seed stock was obtained from a local commercial hatchery (Middle Peninsula Aquaculture Corporation, North, VA). The substitute seed was produced in the summer of 1999 and held through the fall and winter in land-based upwellers at the commercial hatchery site. The seed was produced from second-generation brood stock clams that were originally derived from a cross of moderate salinity North River, Virginia wild clams and a commercial hatchery stock containing selected Virginia and Florida clams.

All plots were replanted as described above for the original planting regimen, receiving 1,250 clams per plot, except for the Florida stock plots, which received only 716 clams per plot because of limited availability of seed. Samples taken from the new plantings were examined in the same manner as initial plants.

\section{Sampling Strategy}

Clam size, condition, survival, and QPX prevalence and intensity were assessed in April/May, August/September, and November/December 2000; April/May, August and November 2001; and April 2002. On each sample date clams were sampled from each replicate plot by random coring. Grids were overlaid over plots and grid blocks were randomly selected for coring. Core size varied depending on sediment conditions at each particular site. In Virginia five 15.2-cm diameter cores were sampled (total area $0.091 \mathrm{~m}^{2}$ ). In New Jersey, which had muddier sediments, it was necessary to use a smaller core and ten $10.2-\mathrm{cm}$ diameter cores were taken (total area $0.081 \mathrm{~m}^{2}$ ). The numbers of live and dead (articulated valves, known as "boxes" and paired disarticulated valves) clams within each core were enumerated for the determination of survival/mortality rates. Shell length, height, and width of 25 clams from each plot were measured. Instantaneous (daily) growth rates were calculated for each sampling interval. Clam samples for disease diagnosis $(n=15)$ and for the determination of condition index $(n=10)$ were collected from pooled core samples for each plot, yielding a composite sample size of 60 for disease diagnosis and 40 for condition index of each stock at each location.
On the final sample date, all plots were completely dug to remove all remaining live and dead clams. In New Jersey, plots were dug manually by rake and hand. In Virginia plots were dug using a hydraulic dredge. All live and dead clams were enumerated for calculation of final mortality estimates.

\section{Disease Diagnosis}

Gross and histological evaluations of clams sampled at each sampling period from each plot were conducted in a standardized, systematic method. After samples were collected they were immediately transported to the respective laboratory, maintained at $4^{\circ} \mathrm{C}$ and usually processed within 18-96 h. Shell size (length, height, and width), total weight, external shell characteristics (such as localized or generalized checks in the shell, gaping, chips or any other external characteristic) were noted for each animal. The clams were then shucked and examined grossly for any abnormal swellings or nodules in the mantles, which can signify the presence of QPX. Tissues were fixed in Davidson's AFA (alcohol, formalin, and acetic acid) solution (Shaw \& Battle 1957).

Clams $<25 \mathrm{~mm}$ in shell height were sectioned sagittally and both sections were embedded, cut face down, for histological analysis. For larger clams, three tissue pieces were embedded and sectioned. The first piece was a transverse section through the clam that included the digestive gland, gonad, gills, mantle and stomach, and foot (posterior dorsal to anterior-ventral). The second piece of tissue contained heart, kidney, and pericardial tissue. The third was a small section of mantle dissected from the area adjacent to the siphons where QPX cells often lodge. Tissues were processed in paraffin in one or two blocks (depending on animal size and noted lesions), sectioned at $6 \mu \mathrm{m}$ and stained using standard methods. The intensity of QPX was assessed for each of the five tissue types within an individual section: mantle, gill, dorsal tissues (heart, kidney, pericardium, and dorsal intestine), ventral tissues (ventral intestine, foot, ganglion, and sinus), and visceral mass. Intensity was scored based on the estimated number of live parasites: $1=1-5,2=6-25,3=26$ 50 , and $4=>50$ per tissue type. Infection intensity scores for each of the five tissue locations were summed to yield a QPX intensity index. Histological and gross observations, along with morphometric measurements, were tracked for each individual clam.

\section{Condition Index}

Condition index is commonly used to evaluate the overall condition of the organism. The calculation of the condition index used in this study normalizes the dry soft tissue mass of the clam to the shell cavity volume.

Individual clams were labeled and weighed. Clams were shucked and soft tissues were removed, weighed, and dehydrated in a $60^{\circ} \mathrm{C}$ oven for $48 \mathrm{~h}$, after which they were reweighed. Condition index (CI) was calculated by the formula

$$
\mathrm{CI}=\text { tissue dry weight } / \text { (total weight }- \text { shell weight })
$$

in which the shell cavity volume is equated to the weight of the tissue and fluid contained therein, under the assumption that they have a specific gravity of approximately $1\left(1 \mathrm{gm} \mathrm{mL}^{-1}\right)$ (Lawrence \& Scott 1982). 


\section{Water Parameters}

Temperature data loggers (Onset Hobo, Bourne, MA) were deployed at each site for the continuous monitoring of temperature on an hourly basis. Salinity was measured using hand held refractometers on all sample dates and periodically between sample dates.

\section{Statistical Analysis}

The significance of the effects of clam stock and block on hard clam growth (length, height, width, whole weight), condition, survival, and QPX prevalence and intensity index by date was determined by a two-way analysis of variance (Zar 1984) using SAS statistical software (SAS Institute Inc, Cary, NC, USA). Mortality and prevalence values were arcsine transformed prior to analysis and all data were examined for homogeneity of variance using Cochran test (Winer 1971). Main effects of stock and block (= plot) and the interaction of stock and block were tested for dependent variables (size, condition, and QPX intensity index) that had within block subsampling using the type III mean square for the interaction of stock and block as an error term. Differences in mean variables between stocks were further examined by Scheffé multiple comparison test. Prevalence and mortality data were arcsine transformed prior to analysis. Spearman Rank correlation tests were conducted to examine the relationship of QPX prevalence and mortality. Differences were considered significant at $\alpha=0.05$.

\section{RESULTS}

\section{Temperature}

In Virginia mean monthly temperatures during the study period ranged from $2.9^{\circ} \mathrm{C}$ to $27.7^{\circ} \mathrm{C}$ (Fig. 2). In New Jersey temperatures were generally $1^{\circ} \mathrm{C}$ to $3^{\circ} \mathrm{C}$ lower than at the Virginia site and mean monthly temperature during the study ranged from $0.1^{\circ} \mathrm{C}$ to $25.3^{\circ} \mathrm{C}$ (Fig. 2).

\section{Growth}

Average shell length of seed clams at the time of planting at the Virginia site in October 1999 ranged from 8.6-9.6 mm (Fig. 3). Florida clams appeared larger, but they differed significantly only from the Virginia stock, which had the smallest mean shell length of the five stocks. The effect of stock on shell length was significant in spring, summer, and fall 2000 but not thereafter. On the final sample date in April 2002, $2.5 \mathrm{y}$ post planting, mean shell lengths of the five stocks ranged from $48.3-52.0 \mathrm{~mm}$ (Table 1 and Fig. 3). Similar trends were observed for shell height and width, and whole weight. On nearly all sample dates the effects of block, and stock by block interactions, on the variables length, height, and width were significant indicating that the effect of stock on these variables was to some degree dependent on location within the block. Daily growth rates for each sampling interval did not differ significantly among the five clam stocks (Fig. 4).

In New Jersey average shell length of seed clams at the time of replanting in June 2000 ranged from 9.3-15.9 mm (Fig. 3). Florida clams were significantly larger than all other stocks at planting and the VA clams were significantly smaller than all other stocks, which were statistically similar in size. Over the course of the study VA clams were consistently the smallest, and

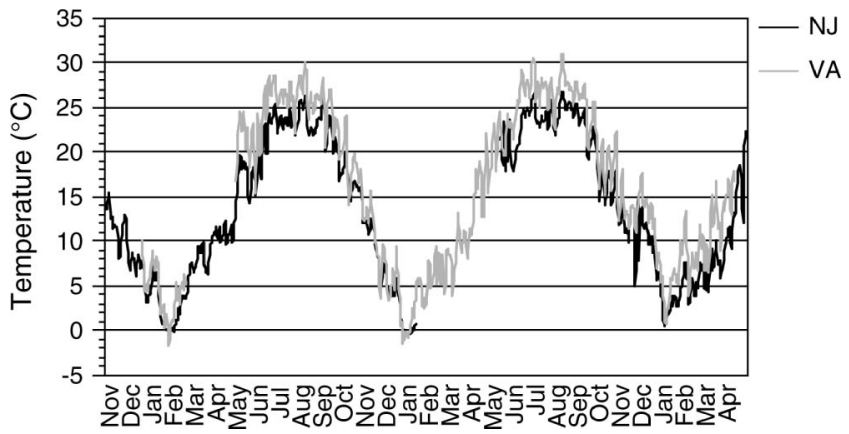

Figure 2. Daily temperature $\left({ }^{\circ} \mathrm{C}\right)$ at the Virginia and New Jersey hard clam grow-out sites from October 1999 through April 2002.

SC and FL were consistently the largest (Fig. 3). On the final sample date, April 2002, mean shell lengths of the five stocks ranged from 39.4-46.5 $\mathrm{mm}$ (Table 2). Mean shell length of the FL and SC clams was significantly larger than that of the VA clams and the SC clams were significantly larger than the MA clams. Similar trends were observed for mean shell height, width, and whole weight. As in Virginia, on nearly all sample dates the effects of block and stock by block interactions on the variables length, height, and width were significant, indicating that the effect of stock on these variables was to some degree dependent on placement within the blocks. Daily growth rates, calculated for each sampling interval, did not significantly differ among the five clam stocks (Fig. 4).
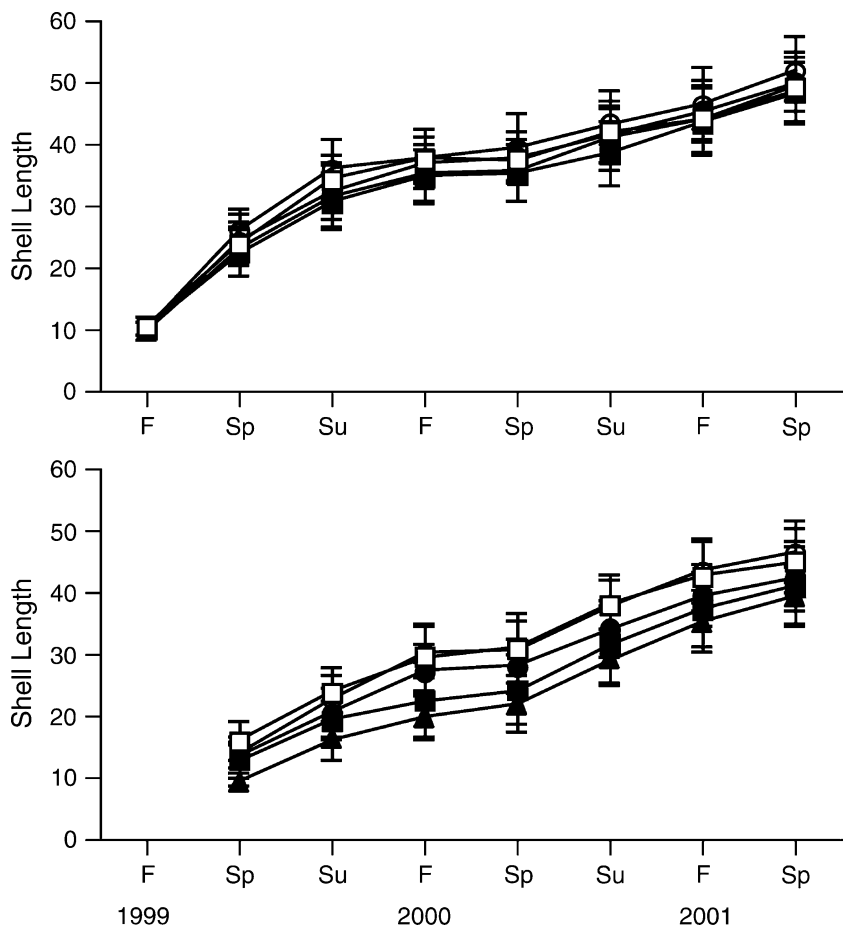

Figure 3. Mean shell length ( $\mathrm{mm}$ ) of hard clams from the Virginia (top) and New Jersey (bottom) grow-out sites from time of planting, fall 1999 for Virginia and spring 2000 for New Jersey, through the termination of the experiment in spring 2002. Means are contrasted for the 5 clam stocks tested: Massachusetts ( $-\longrightarrow$ MA), New Jersey $(-\longrightarrow$ NJ), Virginia $\left(\neg \_\right.$VA), South Carolina ( $\multimap-$ SC), and Florida $(-\square-$ FL). Error bars represent standard deviation ( $n=3$ for Virginia and $n=4$ for New Jersey). 
TABLE 1.

Virginia site. Two-way ANOVA for effects of stock and block and multiple comparison (Scheffé's test) for difference between stock means of variables measured on the final sample date. Means with like scripts do not significantly differ.

\begin{tabular}{|c|c|c|c|c|c|c|c|}
\hline Variable & Effect & df & MS & $F$ & $P$ & Mean & Stock \\
\hline \multirow[t]{5}{*}{ Shell length } & Stock & 4 & 208.054 & 1.96 & 0.1704 & 52.03 & $\mathrm{SC} \mathrm{a}$ \\
\hline & Block & 3 & 332.825 & 16.94 & $<0.0001$ & 50.04 & FL a \\
\hline & Stock $\times$ Block & 12 & 106.128 & 5.40 & $<0.0001$ & 49.36 & $\mathrm{NJ}$ a \\
\hline & & & & & & 48.56 & MA a \\
\hline & & & & & & 48.33 & VA a \\
\hline \multirow[t]{5}{*}{ Condition index } & Stock & 4 & 1.209 & 0.51 & 0.7272 & 6.45 & MA a \\
\hline & Block & 3 & 5.708 & 5.05 & 0.0022 & 6.23 & $\mathrm{SC} \mathrm{a}$ \\
\hline & Stock $\times$ Block & 12 & 2.354 & 2.08 & 0.0239 & 6.22 & FL a \\
\hline & & & & & & 6.09 & $\mathrm{NJ}$ a \\
\hline & & & & & & 6.01 & VA a \\
\hline \multirow[t]{5}{*}{ Mortality } & Stock & 4 & 0.1871 & 29.57 & $<0.0001$ & 77.98 & FL a \\
\hline & Block & 3 & 0.0182 & 2.87 & 0.0846 & 51.75 & $\mathrm{SC} \mathrm{b}$ \\
\hline & & & & & & 35.78 & VA bc \\
\hline & & & & & & 32.70 & MA bc \\
\hline & & & & & & 20.44 & $\mathrm{NJ} \mathrm{c}$ \\
\hline \multirow[t]{5}{*}{ QPX Prevalence } & Stock & 4 & 0.0017 & 11.57 & 0.0006 & 28.9 & FL a \\
\hline & Block & 3 & 0.0031 & 2.05 & 0.1652 & 21.3 & $\mathrm{SC} \mathrm{a}$ \\
\hline & & & & & & 10.0 & VA $a b$ \\
\hline & & & & & & 1.7 & $\mathrm{NJ} b$ \\
\hline & & & & & & 0 & MA b \\
\hline \multirow[t]{5}{*}{ QPX intensity } & Stock & 4 & 12.842 & 5.92 & 0.0086 & 1.33 & FL a \\
\hline & Block & 3 & 1.264 & 0.67 & 0.5721 & 0.50 & $\mathrm{SC} \mathrm{a}$ \\
\hline & Stock $\times$ Block & 12 & 2.168 & 1.15 & 0.3250 & 0.23 & VA $a b$ \\
\hline & & & & & & 0.10 & $\mathrm{NJ} b$ \\
\hline & & & & & & 0.00 & MA b \\
\hline
\end{tabular}

\section{Condition}

Little variability in condition index was observed among clam stocks at either site (Fig. 5). Mean condition indices were highest in summer and spring and lowest in the fall. Statistically significant differences in condition index among stocks were observed on some dates, but a consistent trend among stocks was not apparent. In general the NJ and MA clams had the highest condition indices at both sites.

\section{Mortality}

Differences among strains with respect to survival were striking, particularly in the second and third year of the investigation. In Virginia the first estimate of mortality was made in May 2000, eight months after planting. Mean mortality at this time ranged from $18 \%$ to $32 \%$ with no significant differences among stocks (Fig. 6). Estimated mortality changed little through October 2000 and ranged from $10 \%$ to $45 \%$ in spring and summer 2001. The effect of stock on mortality was significant in spring 2001, but not in summer 2001. In the spring, mortality in the FL and MA clams was significantly higher than that in the SC stock. In fall 2001 differences among stocks were greater because mortality of FL clams increased from $45 \%$ in August to $60 \%$ in November. At this time, mortality in the FL clams was significantly higher than that in the NJ and MA stocks, which respectively exhibited $28 \%$ and $16 \%$ mortality. At the termination of the experiment in April 2002, based on total counts of all live and dead clams remaining in the plots, final mean cumulative mortality was determined to be $78 \%$ in $\mathrm{FL}, 52 \%$ in $\mathrm{SC}, 36 \%$ in VA, $33 \%$ in MA, and $20 \%$ in NJ clams
(Table 1). Mortality in the FL stock was significantly higher than all other stocks. Mortality in the SC stock was significantly higher than in the NJ stock. Total harvest yield demonstrated similar rankings of losses among stocks (Table 3).

In New Jersey, the first estimate of mortality was made in November 2000, five months after replanting. Mean mortality of the five stocks at this time ranged from $14.9 \%$ to $40.1 \%$, but no significant differences among stocks were found (Fig. 6). In May 2001 mean mortality was estimated to be $22.1 \%$ in the NJ clams, $23.5 \%$ in the MA clams, $40.6 \%$ in the VA clams, $42.9 \%$ in the SC clams, and $63.6 \%$ in the FL clams. Differences among stocks were not statistically significant. In November 2001 mortality was significantly higher in VA, SC, and FL clams $(51.3,60.4$, and $77.4 \%$, respectively) than in MA and NJ clams (26.4 and $24.7 \%$ ). At the termination of the study, based on total live and dead counts, mortality was estimated to be $52.7 \%$ in FL clams, 39.8\% in SC clams, $19.6 \%$ in VA clams, $4.3 \%$ in NJ clams, and $6.2 \%$ in MA clams (Table 2). Mortality in the FL stock was significantly higher than that of MA, NJ, and VA clams, but it did not significantly differ from the SC stock. Mortality in the SC clams was significantly higher than MA and $\mathrm{NJ}$, but did not differ significantly from VA, which did not differ significantly from the two more northern stocks. As in Virginia, total harvest yield demonstrated similar ranking of losses among stocks (Table 3).

\section{QPX Prevalence}

QPX prevalence is based on individuals having detectable infections containing live QPX cells. Some additional individuals had infections containing moribund or dead QPX with no live QPX cells apparent (Table 4). QPX was not detected in clams 

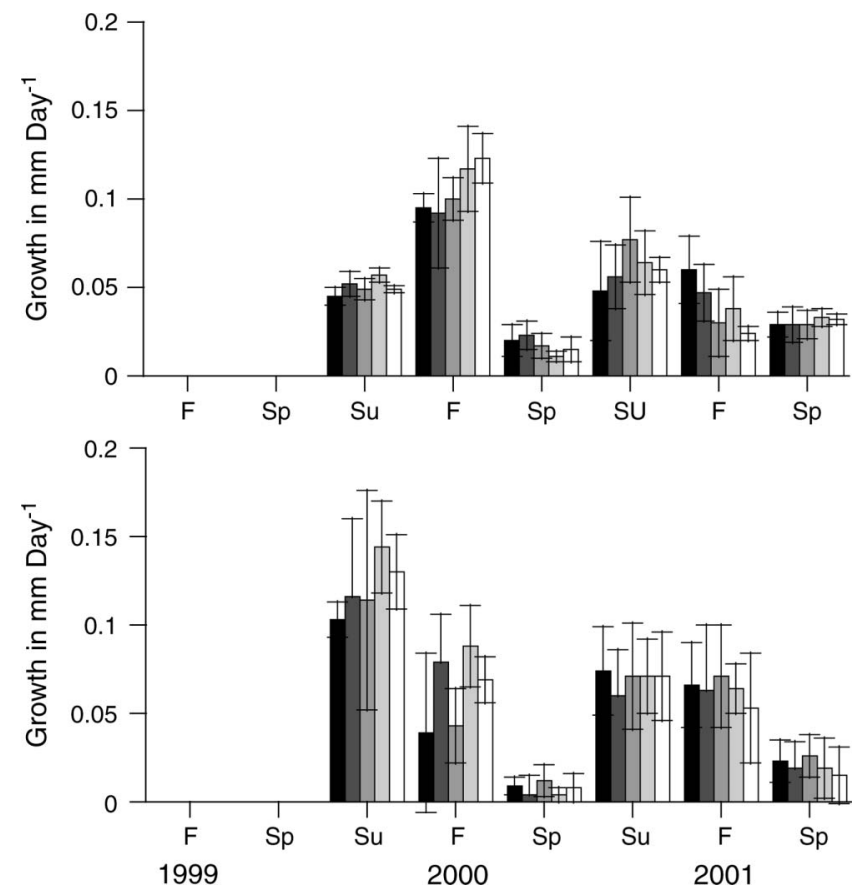

Figure 4. Mean growth per day $(\mathrm{mm})$ of hard clams from the Virginia (top) and New Jersey (bottom) grow-out sites from time of planting, fall 1999 for Virginia and spring 2000 for New Jersey, through the termination of the experiment in spring 2002. Means are contrasted for the 5 clam stocks tested: Massachusetts ( $\square$ MA), New Jersey ( $\square$ NJ), Virginia ( $\square$ VA), South Carolina ( $\square$ SC), and Florida ( $\square$ FL). Error bars represent standard deviation ( $n=3$ for Virginia and $n=4$ for New Jersey).

sampled at the initiation of the experiment in October 1999, nor in May 2000. In Virginia, clams began to exhibit detectable infections in July 2000, less than one year after planting (Fig. 7). Mean prevalence was $11 \%$ in FL clams, significantly higher than in the other four stocks $(0 \%$ to $3 \%)$. No infections were detected in clams sampled in fall 2000; however, in May 2001 infections were observed in all clam stocks: $10 \%$ in SC, $9 \%$ in FL, 7\% in NJ, 3\% in VA, and 2\% in MA. In August 2001 and November 2001, prevalence remained low in MA, NJ, and VA clams $(0-4 \%)$, but significantly increased in SC and FL to $19 \%$ to $20 \%$ and $27 \%$ to $29 \%$ respectively. On the final sample date in spring 2002, QPX prevalence remained high in the SC and FL stocks $(21 \%$ and $29 \%$ respectively) and prevalence in the VA clams increased to $10 \%$. Prevalence in the SC and FL clams was again significantly higher than in the NJ and MA clam stocks, but not from that in the VA clams (Table 1). QPX prevalence significantly correlated with mortality in summer and fall 2001 and spring 2002 (Table 5).

QPX was first observed in clams planted at the New Jersey site in May 2001, 11 mo after planting. Prevalence at this time was $10 \%$ in $\mathrm{FL}, 8 \%$ in $\mathrm{VA}, 7 \%$ in $\mathrm{SC}, 2 \%$ in $\mathrm{MA}$, and $0 \%$ in $\mathrm{NJ}$ (Fig. 6). QPX was detected only in VA and FL stocks in August 2001 at respectively $10 \%$ and $5 \%$ prevalence. In November 2001 QPX prevalence was $18.3 \%$ in $\mathrm{FL}, 15 \%$ in $\mathrm{SC}$ and significantly higher than the $0 \%$ in the three more northern stocks. On the final sample date in April 2002, QPX prevalence in MA and $\mathrm{NJ}$ clams ( 0 and $5 \%$, respectively) was significantly lower than that in SC clams $(38.3 \%)$. Prevalence in the FL clams $(11.7 \%)$ and the VA clams $(18.3 \%)$ did not differ significantly from the other three stocks. QPX prevalence significantly correlated with mortality in May, August and November 2001, and April 2002 (Table 5).

\section{QPX Infection Characterization}

Infection intensity, like prevalence, showed no obvious seasonal pattern. Mean infection intensities were relatively low until the August 2001 sample in Virginia when intensity in the FL stock began to climb rapidly and that of the SC stock began a more gradual increase (Fig. 8). In Virginia, FL and SC clams generally exhibited the highest QPX intensities among the five tested stocks. The effect of stock on QPX intensity was significant on the two final sample dates. In spring 2002, infection intensities in the FL and SC stocks were significantly higher than in the $\mathrm{NJ}$, and MA, whereas the intensity in the VA stock did not significantly differ from the more northern or southern stocks (Table 1). With the exception of the MA stock, which had only 4 individuals with detectable infections during the entire study, the distribution of QPX within host tissues was fairly consistent among stocks. The most frequently observed infection location was mantle tissue; between $46 \%$ and $52 \%$ of the infected individuals from the FL, SC, VA, and NJ exhibited infections that were restricted to the mantle. No mantle infections were observed in the few infected MA clams. Although less common, in all stocks, infections were also observed in various combinations involving mantle, gill, visceral mass, dorsal, and ventral tissues.

In New Jersey also, intensity generally remained $<0.5$; only the SC showed a pronounced intensity peak, but not until the final sample in April 2002 (Fig. 8). Clams from the FL, SC, and VA stocks generally exhibited similar QPX intensity, which was higher than that in the MA and NJ stocks (Fig. 8). The effect of stock on QPX infection intensity was significant only in spring 2002 when intensities in the SC and VA stocks were significantly higher than that in the NJ and MA clams, whereas intensity in the FL stock did not differ significantly from the others. Infections at the New Jersey location, as in Virginia, most commonly occurred in mantle tissue $(48 \%)$.

In general, regardless of stock, lower-intensity infections tended to be localized in mantle tissue, whereas more severe infections were more likely to be multifocal and encompass more than one tissue type. There did not appear to be a strong association between clam stock and the distribution of the parasite within host tissues at either grow-out location.

\section{DISCUSSION}

A common-garden experiment was conducted at two geographically separate sites to examine the effect of host genetic origin and geographic location of growout on QPX disease in hard clams. Progeny of five commercially popular and important hard clam stocks from five states were hatchery reared at a single location and transplanted to grow-out sites in Virginia and New Jersey. The northern stocks, Massachusetts and New Jersey, consistently had the lowest QPX levels and the best survival.

The results of this investigation demonstrate clearly that susceptibility of hard clams to QPX significantly varies with stock origin. The northern stocks consistently had the lowest QPX levels and the best survival. At the New Jersey and 
TABLE 2.

New Jersey site. Two-way ANOVA for effects of stock and block and multiple comparison (Scheffé's test) for difference between stock means of variables measured on the final sample date. Means with like scripts do not significantly differ.

\begin{tabular}{|c|c|c|c|c|c|c|c|}
\hline Variable & Effect & df & MS & $F$ & $P$ & Mean & Stock \\
\hline \multirow[t]{5}{*}{ Shell length } & Stock & 4 & 847.240 & 8.86 & 0.0014 & 46.51 & $\mathrm{SC}$ a \\
\hline & Block & 3 & 14.886 & 0.53 & 0.6600 & 45.02 & FL ab \\
\hline & Stock $\times$ Block & 12 & 95.609 & 3.42 & $<0.0001$ & 42.48 & NJ abc \\
\hline & & & & & & 40.93 & MA bc \\
\hline & & & & & & 39.39 & VA c \\
\hline \multirow[t]{5}{*}{ Condition index } & Stock & 4 & 8.630 & 0.37 & 0.8231 & 7.19 & MA a \\
\hline & Block & 3 & 4.064 & 1.12 & 0.3424 & 7.71 & FL a \\
\hline & Stock $\times$ Block & 12 & 5.779 & 1.59 & 0.0971 & 7.69 & $\mathrm{SC} \mathrm{a}$ \\
\hline & & & & & & 7.37 & $\mathrm{NJ}$ a \\
\hline & & & & & & 7.27 & VA a \\
\hline \multirow[t]{5}{*}{ Mortality } & Stock & 4 & 0.2845 & 21.78 & $<0.0001$ & 52.7 & FL a \\
\hline & Block & 3 & 0.0086 & 0.66 & 0.5942 & 39.8 & $\mathrm{SC} a b$ \\
\hline & & & & & & 19.6 & VA bc \\
\hline & & & & & & 6.1 & MA c \\
\hline & & & & & & 4.3 & NJ c \\
\hline \multirow[t]{5}{*}{ QPX Prevalence } & Stock & 4 & 0.2467 & 6.42 & 0.0053 & 38.3 & $\mathrm{SC}$ a \\
\hline & Block & 3 & 0.0493 & 1.12 & 0.3805 & 18.3 & VA ab \\
\hline & & & & & & 11.7 & FL ab \\
\hline & & & & & & 5.0 & $\mathrm{NJ} b$ \\
\hline & & & & & & 0 & MA b \\
\hline \multirow[t]{5}{*}{ QPX intensity } & Stock & 4 & 20.2916 & 7.83 & 0.0024 & 1.45 & $\mathrm{SC} \mathrm{a}$ \\
\hline & Block & 3 & 1.7722 & 1.04 & 0.3754 & 0.52 & VA a \\
\hline & Stock $\times$ Block & 12 & 2.5916 & 1.52 & 0.1161 & 0.38 & FL ab \\
\hline & & & & & & 0.07 & $\mathrm{NJ} b$ \\
\hline & & & & & & 0.00 & MA b \\
\hline
\end{tabular}

Virginia sites, the South Carolina and Florida clam stocks exhibited significantly higher QPX prevalences and lower survival than the New Jersey and Massachusetts stocks. Clams from Virginia had QPX prevalence and survival rates that were intermediate between the "northern" and "southern" stocks. Though it is premature to state that all Massachusetts or New Jersey clam stocks are more resistant to QPX than all southern stocks, our results are supported by anecdotal and published (Ford et al. 2002) evidence suggesting that clams of southern origin are more susceptible to QPX than local Virginia, New Jersey, or Massachusetts stocks. The most severe QPX disease associated losses of commercially cultured clams in Virginia occurred in stocks originating from Florida (Ragone Calvo, unpublished). Reports of clam producers indicate that in New Jersey and Virginia, QPX epizootics in cultured hard clams have abated following the voluntary (New Jersey) and mandatory (Virginia) restrictions on importing clam seed produced from South Carolina and Florida brood stocks. Likewise in Massachusetts, QPX-associated mortalities of cultured hard clams have decreased because the practice of importing seed from outof-area stocks has ceased (R. Smolowitz, unpublished). Nevertheless, in Massachusetts, significant losses still occur despite the use of local clam seed, which proved to be highly resistant to QPX in our study. Other factors, aside from host genotype, such as environmental conditions and parasite abundance, may explain the persistent epizootics in Massachusetts.

Variation in resistance to disease by geographically distinct populations has been demonstrated for oysters (Haskin \& Ford 1979, Bushek \& Allen 1996), but our study is the first to clearly document this for hard clams. The marked differences in QPX susceptibility among stocks, suggests that there is a high degree of genetic control of this trait. Several studies have indicated that growth and survival traits in hard clams are heritable (Hilbish 2001). Quantitative genetic analyses have demonstrated a high degree of genetic variation in growth rates in wild and cultured hard clam populations (Hilbish 2001, Camara et al. 2006). Clams having genes from southern population appear to exhibit higher growth rates than those having genes from more northern populations. Additionally, there is some indication that the magnitude of genetic variation in these traits depends on the environment in which the hard clams are grown (Rawson \& Hilbish 1991, Camara et al. 2006). Consistently we found considerably larger differences in mean size among stocks at the final sampling in New Jersey compared with Virginia (see Tables 1 and 2). The significant stock $\mathrm{x}$ block interactions in our study indicate that environmental differences over even very short distances can have a marked effect on clam growth. It seems that particular stocks responded better to certain very local conditions (i.e., downstream vs. upstream, offshore vs. inshore, center vs. edge). Although we found no stock x block interactions with respect to QPX infections in our experimental sites, genotype-environment interactions over longer distances may help explain variation in QPX susceptibility among different hard clam source populations. Additional common garden experiments conducted in multiple environments using more than one stock from each region are required to further assess this hypothesis.

In comparing the overall performance among stocks within and between sites it is important to keep in mind that at the New Jersey site the FL stock, because of limited availability, was 

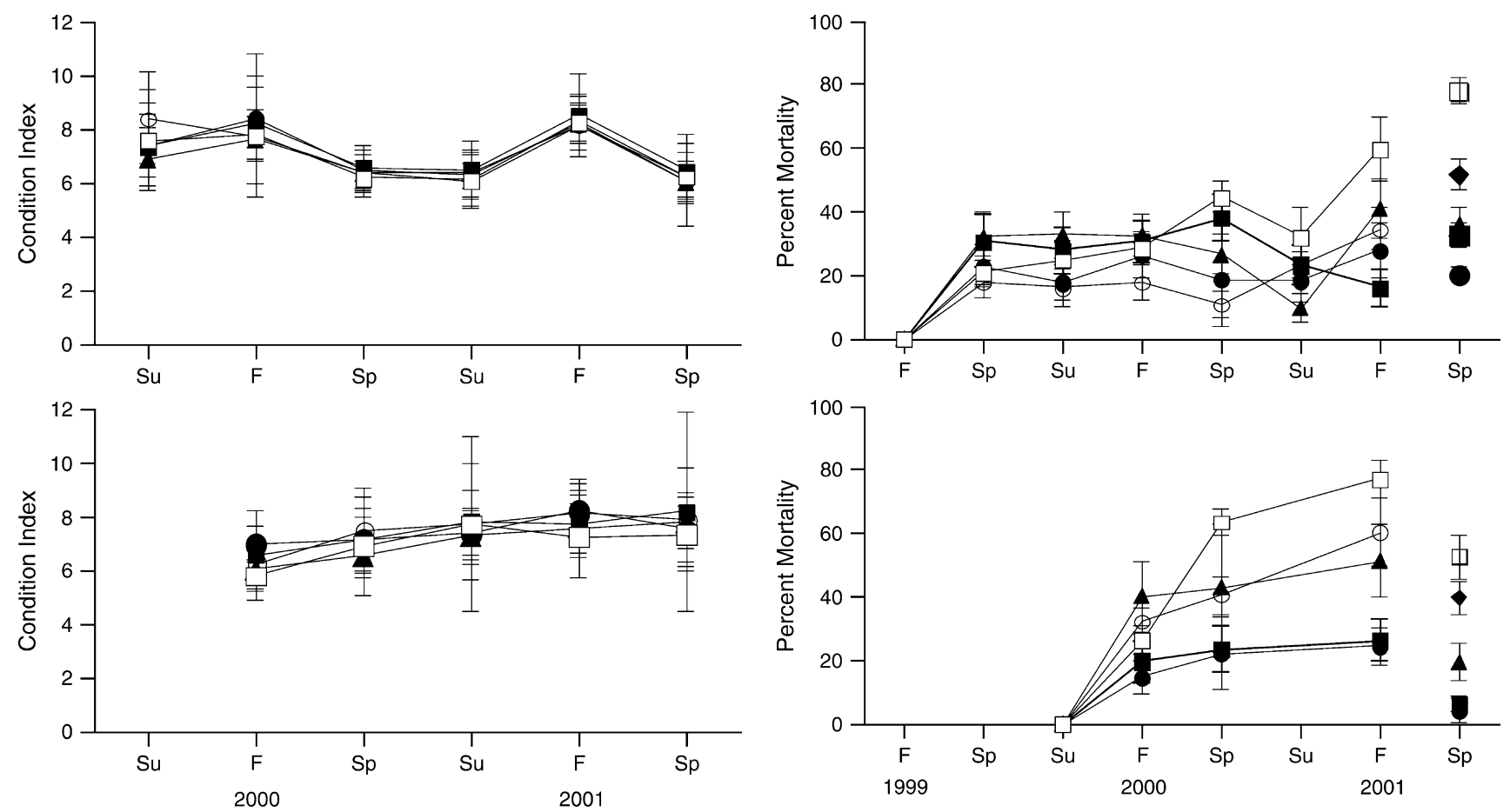

Figure 5. Mean condition index of hard clams from the Virginia (top) and New Jersey (bottom) grow-out sites from summer 2000 for Virginia and fall 2000 for New Jersey through the termination of the experiment in spring 2002. Means are contrasted for the 5 clam stocks tested: Massachusetts ( - MA), New Jersey $(\multimap-$ NJ), Virginia $(\neg-$ VA), South Carolina $(-\odot-S C)$, and Florida $(-\square-$ FL). Error bars represent standard deviation ( $n=3$ for Virginia and $n=4$ for New Jersey).

planted at about half the density of the other four stocks. One would expect lower planting densities to result in higher growth rates as well as to impede parasite transmission resulting in lower infection rates. In contrast, the FL clams, which were not only at low density, but larger at the time of planting, did not maintain a proportionately higher mean shell length in comparison with the other four stocks, and at times had the highest QPX and mortality at the site. We must also note that between-site comparisons of the Virginia source stocks should only be made with the caveat that the VA stocks used in New Jersey and Virginia were produced from different brood stocks and under different conditions. Nevertheless, the relative performance of the VA and FL stocks at the New Jersey and Virginia sites was similar.

Initial mortality estimates were made in Virginia in May 2000 , eight months after planting and in New Jersey in November 2000, five months after replanting. At this time mortality ranged from about $15 \%$ to $40 \%$. This initial mortality was not associated with QPX infections and was likely related to planting stress or small predators, and in the case of the Virginia planting, winter-associated stress. The early mortality is consistent with that typically observed in commercial clam culture operations. In Virginia, QPX prevalence maxima were $10 \%$ in the FL and SC stocks, and $<5 \%$ in the others through spring 2001, but beginning that summer, both prevalence and intensity began to rise in the FL and SC stocks. Thereafter, a significant and positive correlation existed between QPX prevalence and mortality, suggesting an associ-

Figure 6. Mean percent mortality of hard clams from the Virginia (top) and New Jersey (bottom) grow-out sites from time of planting, fall 1999 for Virginia and spring 2000 for New Jersey, through the termination of the experiment in spring 2002. Means are contrasted for the 5 clam stocks tested: Massachusetts ( - - MA), New Jersey ( - - NJ), Virginia $(\neg-$ VA), South Carolina ( - SC), and Florida $(\neg-$ FL). Mortality on the final sample date was based on collection clams from whole plots, those on other dates were based on random core samples. Error bars represent standard error ( $n=3$ for Virginia and $n=4$ for New Jersey).

ation of the mortality with progressively developing QPX disease. At the New Jersey site, a significant correlation between QPX prevalence and mortality existed at all sample dates, even though maximum prevalence never exceeded 10\% through summer 2001. Given the low prevalence it seems unlikely that the $50 \%$ to $60 \%$ mortality observed in the FL and SC stocks at this time can be explained by QPX alone. More likely the positive correlation between mortality and QPX may have been a sign of stress in the southern stocks that led to mortality from factors other than QPX as well as in increased susceptibility to infection.

In Virginia, mortality significantly correlated with QPX prevalence on the final three sample dates, summer and fall 2001, and spring 2002. At this time QPX prevalence in the SC and FL stocks ranged between $20 \%$ and $30 \%$ and mortality was estimated to be from about $30 \%$ to $78 \%$. This is consistent with other studies that have shown the occurrence of high mortality at relatively low, 20\% to 48\%, QPX prevalence (Ragone Calvo et al. 1998; R. Smolowitz, unpublished); however, other studies have reported high mortality associated with much higher, up to $80 \%$, QPX prevalence (Ford et al. 2002). Few studies have sampled QPX-infected populations frequently enough to adequately characterize epizootics. To date it seems that the general pattern of QPX epizootics varies from situation to situation. In some instances, high mortality is associated with relatively high prevalence, whereas in other instances, lethal QPX infections may develop at a constant, low rate over time resulting in 
TABLE 3.

Final harvest statistics for clams grown in Virginia and New Jersey including: mean and standard deviation of percent mortality, the total number of live and dead clams removed from plots on the final sample date; mean and standard deviation of percent yield, total number of live clams sampled during and at the end of the study divided by the initial number planted and multiplied by 100; and mean and standard deviation of \% recovery, the total number of live and dead clams sampled during and at the end of the study divided by the initial number planted and multiplied by 100. All means based on $n=4$ except for Virginia FL which had $n=3$.

\begin{tabular}{|c|c|c|c|c|c|c|c|}
\hline Site & Stock & $\%$ Mortality & $S D$ & $\%$ Yield & $S D$ & \% Recovery & $S D$ \\
\hline \multirow[t]{5}{*}{ Virginia } & MA & 32.7 & 7.98 & 43.2 & 16.55 & 61.1 & 20.6 \\
\hline & NJ & 20.4 & 4.52 & 49.4 & 14.23 & 61.1 & 18.4 \\
\hline & VA & 35.8 & 11.27 & 41.8 & 4.29 & 63.4 & 8.1 \\
\hline & $\mathrm{SC}$ & 51.7 & 10.04 & 32.4 & 5.08 & 57.6 & 9.6 \\
\hline & FL & 77.9 & 7.33 & 22.5 & 4.24 & 62.2 & 6.0 \\
\hline \multirow[t]{5}{*}{ New Jersey } & MA & 6.1 & 4.79 & 77.5 & 32.6 & 84.2 & 31.1 \\
\hline & NJ & 4.3 & 0.73 & 82.2 & 12.5 & 87.4 & 12.4 \\
\hline & VA & 19.6 & 11.68 & 28.2 & 19.6 & 40.0 & 18.7 \\
\hline & $\mathrm{SC}$ & 39.8 & 39.79 & 40.6 & 6.1 & 67.9 & 5.3 \\
\hline & FL & 52.7 & 14.14 & 33.7 & 6.9 & 67.6 & 6.7 \\
\hline
\end{tabular}

persistent, but low mortality rates. Thus, a large proportion of the clam population is never detectably infected at any given time, even though cumulative mortality can be high. In the present study, spring, summer, and fall sampling over a period of nearly 3 y enabled an assessment of cumulative mortality during the entire "market" growing period but perhaps did not enable detection of an instantaneous peak in mortality, which may have been evident with a more frequent, monthly sampling scheme.

Field estimation of hard clam mortalities is a challenging task particularly over a period of 2-3 y or longer. QPX infected hard clams tend to rise to the sediment surface and may be washed to net edges and the fragile shells of very small seed clams that die early in the study may disintegrate by the end of the study and be lost from mortality counts. The apparent decline in cumulative mortality between the fall 2001 and spring 2002 samplings in New Jersey may be because of the disintegration of smaller valves during the winter months. Also, hand raking and digging may less effectively recover small dead clams relative to coring and sieving even though one would expect estimates based on the total plot to be more accurate than

TABLE 4.

Percent of examined clams from each site and stock having only live QPX cells, only dead QPX cells, and both live and dead QPX cells (sample sizes ranged from 270-360).

\begin{tabular}{cccc}
\hline \hline $\begin{array}{c}\text { Site \& Clam } \\
\text { Stock }\end{array}$ & $\begin{array}{c}\text { \% Only } \\
\text { Live QPX }\end{array}$ & $\begin{array}{c}\text { \% Only } \\
\text { Dead QPX }\end{array}$ & $\begin{array}{c}\text { \% Live \& Dead } \\
\text { QPX }\end{array}$ \\
\hline Virginia & & & \\
FL & 11.5 & 0 & 5.2 \\
MA & 0.6 & 1.1 & 0.6 \\
NJ & 0.6 & 0.3 & 0.6 \\
SC & 3.6 & 0.6 & 3.6 \\
VA & 1.4 & 0.3 & 1.4 \\
New Jersey & & & \\
FL & 4.7 & 5.8 & 2.8 \\
MA & 0 & 1.4 & 0.3 \\
NJ & 8.3 & 0.6 & 0.6 \\
SC & 7.7 & 0 & 1.9 \\
VA & 4.7 & 2.3 & 1.7 \\
\hline
\end{tabular}

estimates based on random core subsamples. Nevertheless, final sampling mortalities fell into the same rank order as those obtained by core-sampling the previous fall (Fig. 6).

At both the New Jersey and Virginia sites the most severe infections were observed in clams from the FL and SC stocks. Although we did not sample on a frequent basis, we found no evidence of seasonal pattern in QPX prevalence and intensity during the $2.5 \mathrm{y}$ of the study. Rather, the prevalence and intensity pattern in the susceptible clams showed a generally increasing trend over time. High prevalence and intensity was not recorded until year two of the study, and the highest mean intensity was observed on the final sample date in April 2002, supporting previous studies indicating that the disease typically affects clams that have been in the field for approximately 12 or more months (Ford et al. 1997).

The reason for the association of higher QPX susceptibility with clams of southern origin cannot be determined from the present study; however, two hypotheses can be proposed. The first stems from the fact that QPX has never been reported south of Virginia even though clam aquaculture is extensive along the southeastern United States coast. The apparent absence of QPX in this region may be because of its intolerance of high temperature. In culture, QPX cells grow best at $20^{\circ} \mathrm{C}$ to $23^{\circ} \mathrm{C}$ and suffer $50 \%$ mortality at $29^{\circ} \mathrm{C}$ (Brothers et al. 2000; D. Buggé \& B. Allam, SUNY Stony Brook, personal communication, June 2006). Consequently, southern stocks may never have been exposed to selective mortality caused by the parasite. In contrast, northern stocks are likely to have experienced selective mortality, albeit for an unknown period, that may have increased resistance in the surviving populations.

A second hypothesis is that stocks of southern origin, which may be genetically selected for life in a relatively warm environment, are poorly adapted to the colder temperatures of the northern climes. Their ability to mount a defense against invading parasites may be compromised as temperatures decline. Further, Thraustochytrids inhabit the mantle cavities of bivalves (Perkins 1973, Porter 1990), and QPX or QPX-like organisms are present in the pallial fluid of hard clams, as determined by PCR (Lyons et al. 2005). If activity, including filtration rate, of southern clams grown in the north declines faster in the fall and increases more slowly in the spring 

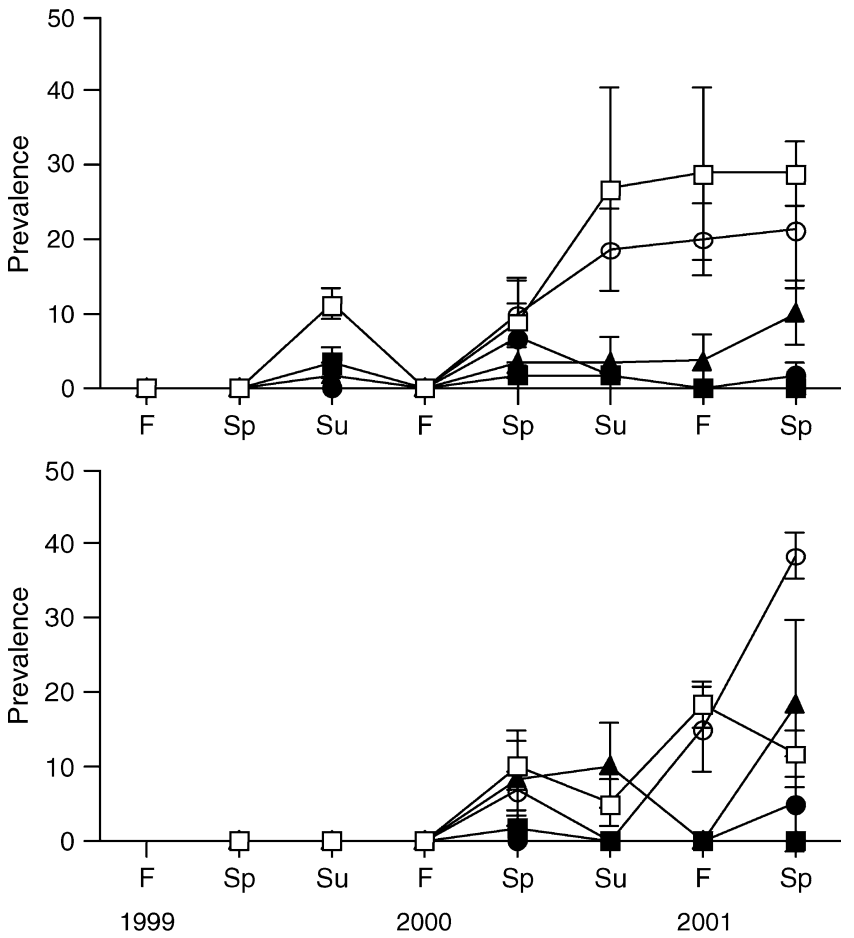

Figure 7. Mean QPX prevalence (\%) of hard clams from the Virginia (top) and New Jersey (bottom) grow-out sites from time of planting, fall 1999 for Virginia and spring 2000 for New Jersey, through the termination of the experiment in spring 2002. Means are contrasted for the 5 clam stocks tested: Massachusetts ( - - MA), New Jersey ( $\rightarrow-$ NJ), Virginia $\left(\neg \_\right.$VA), South Carolina $\left(-\_-\right.$SC), and Florida $(-\square-$ FL) Error bars represent standard error $(n=\mathbf{3}$ for Virginia and $n=4$ for New Jersey).

compared with local stocks, the proliferation and/or accumulation of QPX in the mantle cavity may be favored. It may be relevant in this respect that no QPX infections were detected in the fall 2000 samples, but were found at both sites and in most stocks in the spring of 2001 implying that the parasites had proliferated to detectable levels at relatively low to moderate temperatures and that this had happened to the greatest extent in the southern stocks.

It is not possible, from the available data, to differentiate between these hypotheses. For instance, the apparent failure

TABLE 5.

Spearman rank correlation of QPX and clam mortality by site and date.

\begin{tabular}{cccc}
\hline \hline \multicolumn{1}{c}{ Site } & Date & $\boldsymbol{r}$ & $\boldsymbol{p}$ \\
\hline Virginia & $7-31-00$ & 0.147 & 0.5476 \\
& $5-31-01$ & 0.097 & 0.6916 \\
& $8-16-01$ & 0.456 & 0.0500 \\
& $11-12-01$ & 0.458 & 0.0484 \\
New Jersey & $4-24-02$ & 0.646 & 0.0028 \\
& $5-7-01$ & 0.740 & 0.0013 \\
& $8-17-01$ & 0.529 & 0.0212 \\
& $11-13-01$ & 0.537 & 0.0192 \\
& $4-24-02$ & 0.662 & 0.0039 \\
\hline
\end{tabular}
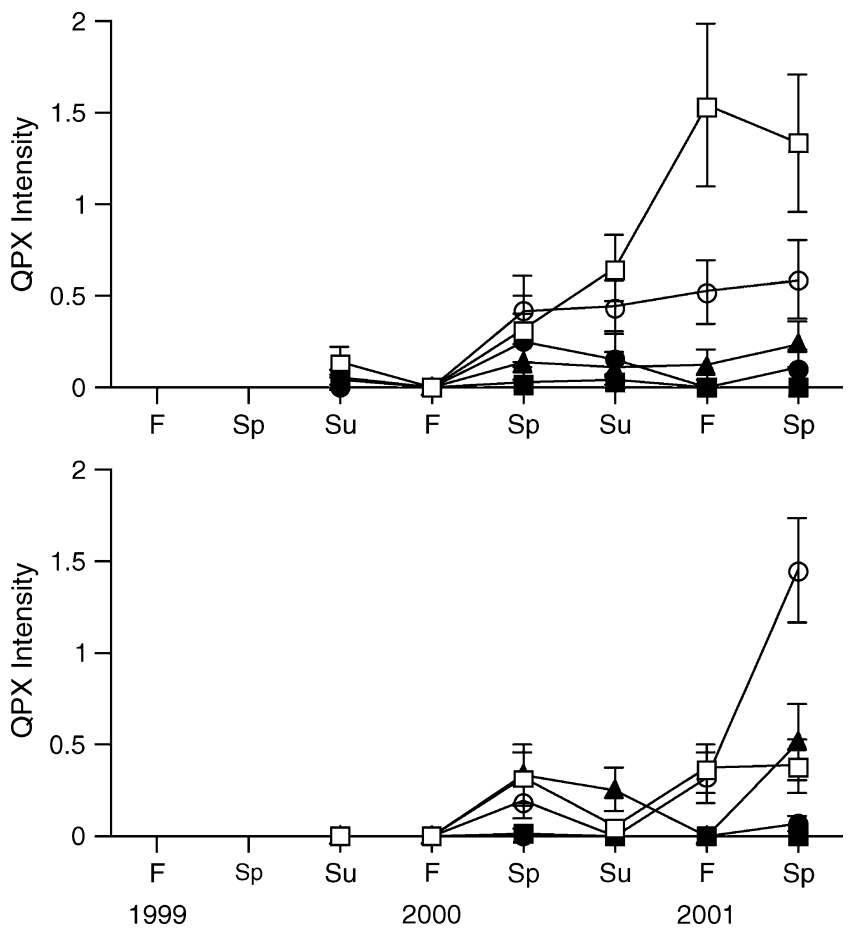

Figure 8. Mean QPX intensity in hard clams from the Virginia (top) and New Jersey (bottom) grow-out sites from time of planting, fall 1999 for Virginia and spring 2000 for New Jersey, through the termination of the experiment in spring 2002. Means are contrasted for the 5 clam stocks tested: Massachusetts ( - - MA), New Jersey ( $\bullet-$ NJ), Virginia $\left(\neg \_\right.$VA), South Carolina ( $\neg-$ SC), and Florida $(-\square-$ FL). Error bars represent standard deviation ( $n=3$ for Virginia and $n=4$ for New Jersey).

of southern stocks to mount an adequate defense against QPX could be because of lack of selection for resistance or to an impaired response at low temperatures. The proposed mechanisms are not mutually exclusive and both may contribute to the observed susceptibility differences.

Prior to the emergence of QPX, hard clam aquaculturists often purchased seed clams from southern hatcheries. The southern seed was more readily available, less costly, available earlier in the season allowing earlier planting and a longer growing season, and/or offered faster growth rates than seed from more northern hatcheries. In the present study growth rates of the FL and SC clam stocks did not differ significantly from the stocks having more northern origins and failed to support anecdotal evidence suggesting that southern clam stocks grow faster than northern clam stocks. However, qualitatively, the southern clams appeared larger than the northern stocks throughout the study at both sites.

This study clearly demonstrates that the genetic origin of clam stocks can have profound effects on hard clam susceptibility to QPX disease. As such, hard clam culturist should consider the geographic origin of clam seed an important component of their QPX disease avoidance/management strategies. In particular, southern stocks should not be used to produce seed to be grown in the area where QPX is enzootic. Our results indicate that two stocks (Massachusetts and New Jersey) had the best survival in both New Jersey and Virginia. These could form the basis for a selective 
breeding strategy for the development of QPX disease resistant stocks.

\section{ACKNOWLEDGMENTS}

Many individuals contributed to the success of this project. The authors thank; in Virginia; Rita Crockett for disease diagnosis, Tom Gallivan and Nate Geyerhahn for oversight of the field component, the many VIMS staff and students who assisted with field collections and clam processing, Dr. Standish Allen and the Aquaculture Genetics and Breeding Center staff for production of clam seed, cooperating industry members who supplied brood stock clams, Dr. Mark Camara for assistance with statistical analyses, and Katherine Davis-Small; for assistance with administration of the grant. The authors also thank; in New Jersey; George Mathis for use of his site; assistance in establishing and maintaining field sites; and for assisting with collections, Robert Barber for histological processing of clams and disease diagnosis, and Beth Mello for managing field collections and clam processing. This project was funded by the Saltonstall-Kennedy Program (Grant Number NA96FD0075). VIMS contribution number 2811.

\section{LITERATURE CITED}

Bower, S. M. 1987. Labyrinthuloides haliotidis n. sp. (Protozoa: Labyrinthomorpha), a pathogenic parasite of small juvenile abalone in a British Columbia mariculture facility. Can. J. Zool. 65:1996-2007.

Brothers, C., E. Marks \& R. Smolowitz. 2000. Conditions affecting the growth and zoosporulation of the protistan parasite QPX in culture. Biol. Bull. 199:200-201.

Bushek, D. \& S. K. Allen, Jr. 1996. Host-parasite interactions among broadly distributed populations of the eastern oyster Crassostrea virginica, and the protozoan Perkinsus marinus. Mar. Ecol. Prog. Ser. 139:127-141.

Camara, M. D., S. K. Allen, Jr., R. B. Carnegie \& K. S. Reese. 2006. Out-crossing among commercial strains of the northern quahog, Mercenaria mercenaria: survival, growth and implications for selective breeding. J. Shellfish Res. 25:403-416.

Dove, A. D. M., P. R. Bowser \& R. M. Cerrato. 2004. Histological analysis of an outbreak of QPX disease in wild hard clams Mercenaria mercenaria in New York. J. Aquat. Anim. Health 16: 246-250.

Fegley, S. R. 2001. Demography and dynamics of hard clam populations. In: J. N. Kraeuter \& M. Castagna, editors. The biology of the hard clam, Mercenaria mercenaria (Linné). 31, Amsterdam: Elsevier Scientific Publishers, pp. 261-280.

Ford, S. E., J. N. Kraeuter, R. D. Barber \& G. Mathis. 2002. Aquaculture associated factors in QPX disease of hard clams: density and seed source. Aquaculture 208:23-38.

Ford, S. E., R. Smolowitz, L. Ragone-Calvo, R. D. Barber \& J. N. Kraeuter. 1997. Evidence that QPX (Quahog Parasite Unknown) is not present in hatchery-produced hard clam seed. J. Shellfish Res. 16:519-521.

Haskin, H. H. \& S. E. Ford. 1979. Development of resistance to Minchinia nelsoni (MSX) mortality in laboratory-reared and native oyster stocks in Delaware Bay. U.S. Mar. Fish. Rev. 41:54-63.

Hilbish, T. J. 2001. Genetics of Hard Clams, Mercenaria mercenaria. In: J. N. Kraeuter \& M. Castagna, editors. The biology of the hard clam, Mercenaria mercenaria (Linné). 31, Amsterdam: Elsevier Scientific Publishers. pp. 261-280.

Lawrence, D. R. \& G. I. Scott. 1982. The determination and use of condition index of oysters. Estuaries 5:23-27.

Lyons, M. M., J. E. Ward, R. Smolowitz, K. R. Uhlinger \& R. J. Gast. 2005. Lethal marine snow: pathogen of bivalve mollusc concealed in marine aggregates. Limnol. Oceanogr. 50:1983-1988.

Maas, P. A. Y., S. J. Kleinschuster, M. J. Dykstra, R. Smolowitz \& J. Parent. 1999. Molecular characterization of QPX (Quahog Parasite Unknown), a pathogen of Mercenaria mercenaria. J. Shellfish Res. 18:561-567.
McLean, N. \& D. Porter. 1982. The yellow spot disease of Tritonia diomedea Bergh, 1894 (Mollusca: Gastropoda; Nudibranchia): encapsulation of the Traustochytreaceous parasite by host amoebocytes. J. Parasitol. 68:243-252.

Menzel, R. W. 1989. The biology, fishery and culture of quahog clams, Mercenaria. In: J. J. Manzi \& M. Castagna, editors. Clam mariculture in North America. Amsterdam: Elsevier. pp. 201-242.

Perkins, F. O. 1973. A new species of marine Labyrinthulid. Arkiv für Mikrobiologie 90:1-17.

Polglase, J. L. 1980. A preliminary report on the Thraustochytrid(s) and Labyrinthulid(s) associated with a pathological condition in the lesser octopus Eledone cirrhosa. Botanica Marina 23:699-706.

Porter, D. 1990. Phylum Labyrinthomycota. In: L. Margulis, J. O. Corliss, M. Melkonian, \& D. J. Chapman, editors. Handbook of rotoctista. Boston: Jones and Bartlett. pp. 388-398.

Ragan, M. A., G. S. MacCallum, C. A. Murphy, J. J. Cannone, R. R. Gutell \& S. E. McGladdery. 2000. Protistant parasite QPX of hardshell clam Mercenaria mercenaria is a member of Labyrinthulomycota. Dis. Aquat. Org. 42:185-190.

Ragone Calvo, L. M., J. G. Walker \& E. M. Burreson. 1998. Prevalence and distribution of QPX, Quahog Parasite Unknown, in hard clams, Mercenaria mercenaria, in Virginia, USA. Dis. Aquat. Org. 33:209219.

Rawson, P. D. \& T. J. Hilbish. 1991. Heritability of juvenile growth for the hard clam Mercenaria mercenaria (L.). Evolution Int. J. Org. Evolution 45:1924-1935.

Shaw, B. L. \& H. I. Battle. 1957. The gross and microscopic anatomy of the digestive tract of the oyster Crassostrea virginica (Gmelin). Can. J. Zool. 35:325-347.

Smolowitz, R., D. Leavitt \& F. Perkins. 1998. Observations of a protistan disease similar to QPX in Mercenaria mercenaria (hard clams) from the coast of Massachusetts. J. Invertebr. Pathol. 71: 9-25.

Stokes, N. A., L. M. Ragone Calvo, K. S. Reece \& E. M. Burreson. 2002. Molecular diagnostics, field validation, and phylogenetic analysis of quahog parasite unknown (QPX), a pathogen of the hard clam Mercenaria mercenaria. Dis. Aquat. Org. 52:233-247.

Whyte, S. K., R. J. Cawthorn \& S. E. McGladdery. 1994. QPX (Quahaug Parasite X) a pathogen of northern quahaug Mercenaria mercenaria from the Gulf of St. Lawrence, Canada. Dis. Aquat. Org. 19:129-136.

Winer, B. J. 1971. Statistical Principles in Experimental Design. New York: McGraw Hill. 907 pp.

Zar, J. H. 1984. Biostatistical analysis. Englewood Cliffs: Prentice-Hall. $718 \mathrm{pp}$. 